\title{
Marine transgression(s) to evaporite basin: The case of middle Miocene (Badenian) gypsum in the Central Paratethys, SE Poland
}

\author{
Danuta Peryt ${ }^{1}$, Przemysław Gedl ${ }^{2}$ and Tadeusz Marek Peryt ${ }^{*}$
}

\begin{abstract}
The middle Miocene Badenian evaporite basin of the Carpathian Foredeep Basin was a saline lake, separated by a barrier from the sea and supplied with seawater seeping through the barrier or overflowing it occasionally in the form of short-lived marine transgressions. Such transgressions could leave behind marine microfossils in marly clay intercalations. One of them ( $2.3 \mathrm{~m}$ thick) occurs in the uppermost part of the sulphate sequence, in the unit ' $\mathrm{o}$ ', in the Babczyn 2 borehole section. It contains marine palynomorphs (dinoflagellate cysts) and foraminiferal assemblages indicating a marine environment. The low-diversity benthic foraminiferal assemblages are dominated by opportunistic, shallow infaunally living species, preferring muddy or clayey substrate for thriving, brackish to normal marine salinity, and inner shelf environment. Dinoflagellate cyst assemblages, although taxonomically impoverished, consist of marine species; euryhaline forms that tolerate increased salinity are missing. Relatively common microfossils found in clay intercalations within gypsum have important palaeogeographical implications: they strongly suggest that there existed an additional inflow channel supplying the Polish Carpathian Basin from the south during the evaporite deposition and afterwards.
\end{abstract}

Keywords: Evaporite basins, Transgression, Microfossils, Badenian, Palaeogeography, Paratethys

\section{Introduction}

The Paratethys was an epicontinental sea that developed as a relic of the Tethys. It existed between early Oligocene and late middle Miocene times and constituted a system of marine basins extending from the Alpine-Carpathian region to the modern Aral Sea during Oligocene to Miocene times. They were periodically connected with the Mediterranean, Indo-Pacific and Atlantic oceans (Rögl 1998). The Paratethys is divided into three segments: Western, Central and Eastern, and the regional time scale, based mostly on endemic fossil assemblages, is applied for particular parts of the

\footnotetext{
*Correspondence: tadeusz.peryt@pgi.gov.pl

${ }^{3}$ Polish Geological Institute-National Research Institute, Rakowiecka 4, 00-975 Warszawa, Poland

Full list of author information is available at the end of the article
}

Paratethys (Fig. 1). Water circulation in the Paratethys was strongly controlled by two shallow and narrow gateways: the Slovenian (Trans-Tethyan Trench) corridor (Rögl 1998; Kováč et al. 2017) and the Bârlad Strait in Romania (Palcu et al. 2015) connecting the Central and Eastern Paratethys. Both gateways were located in tectonically active regions (Simon et al. 2019) and controlled the recorded palaeoenvironmental changes in these basins, although the exact mechanisms are still poorly understood (Palcu et al. 2017). At $13.8 \mathrm{Ma}$, the global climate cooled, triggering a glaciation, which led to a global sea-level fall of $\sim 50-70 \mathrm{~m}$ (John et al. 2011; Simon et al. 2019), which drastically reduced the TransTethyan Strait to a very shallow depth and disconnected the two Paratethyan basins (Fig. 2). The Badenian Salinity Crises ended before $13.32 \pm 0.07 \mathrm{Ma}$ (de Leeuw 


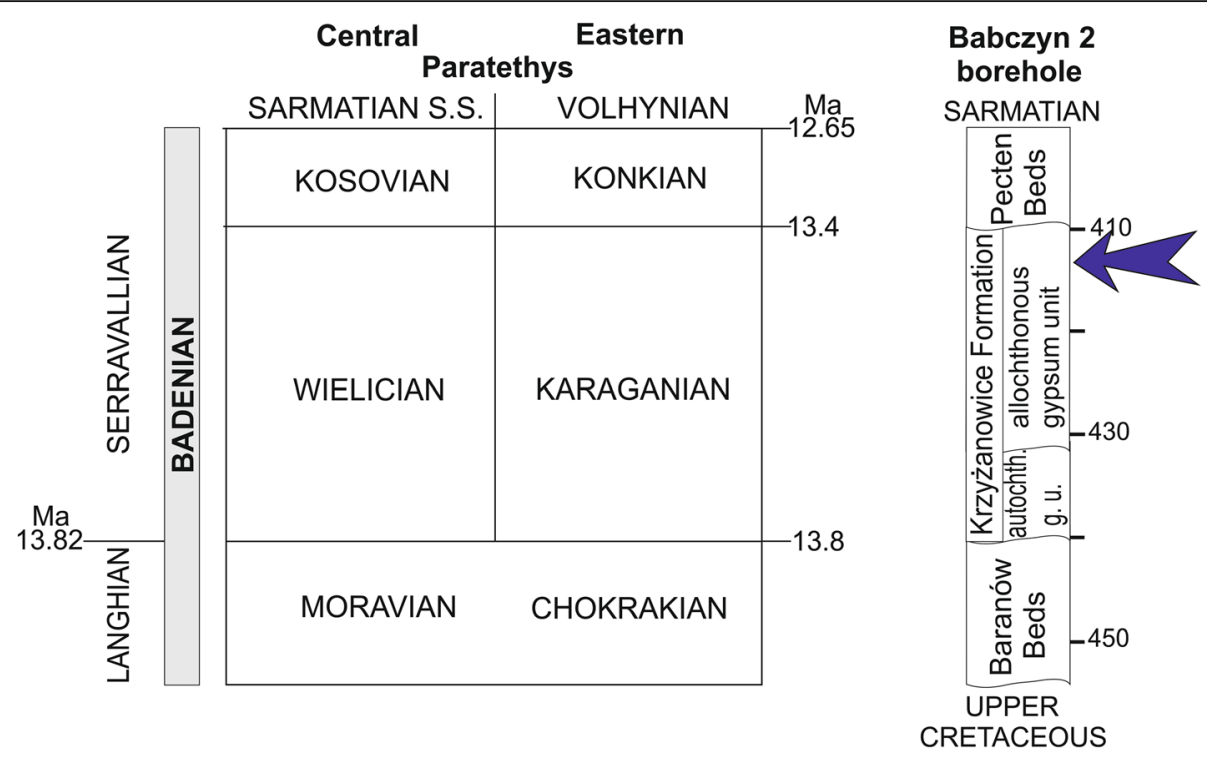

Fig. 1 Regional middle Miocene Paratethyan stratigraphy in comparison with the standard global chronostratigraphy (modified after Śliwiński et al. 2012 and Hilgen et al. 2012, updated by Palcu et al. 2015, 2017) and the occurrence of microfossils-bearing clay intercalation (arrowed) in the Babczyn 2 borehole section. Numbers right of the borehole section indicate the depth (in metres); allochth. g. u. = Autochthonous gypsum unit

et al. 2018). A transgression that re-installed normal marine conditions in the Carpathian Foredeep Basin resulted from reconnection of the basin with the Mediterranean and Eastern Paratethys, primarily by tectonic modification of the interconnecting gateways, i.e. tectonic lowering of the barriers between the Central Paratethys and the neighbouring basins (de Leeuw et al. 2018).

The system of middle Miocene Badenian evaporite basins of the Central Paratethys (Fig. 2), which started to form at some 13.81 Ma, gained occasional connections with the Mediterranean marine reservoir through the Slovenian (Trans-Tethyan Trench) corridor or with the Eastern Paratethys (low-salinity water reservoir - Palcu et al. 2017) through the Bârlad Strait. Barred evaporite basins are sourced mostly by seepage (Kendall 2010; Warren 2016). When overflow happens, then depending on the volume of seawater inflow and the overflow duration, the brines of barred basin may be eventually replaced by seawater. One eminent connection of barred evaporite basin of the Carpathian Foredeep Basin with an open-sea reservoir was previously recognized in the middle part of the gypsum sequence of southern Poland where a marly clay intercalation sandwiched between the gypsum contains benthic and planktonic foraminifera indicating a short-lived inflow of marine water (Peryt 2013a; Fig. 2). The foraminifer-bearing clay intercalation in southern Poland occurs in the middle of the upper part of the gypsum sequence, i.e. at the same stratigraphic position as other foraminifer-bearing clay intercalations in the gypsum sequence, which were recorded by Odrzywolska-Bieńkowa (1975) in SE Poland (cf. Pawłowski et al. 1985; Kos in Kasprzyk 1989; Kubica 1992). In this paper, we report the foraminiferal and dinoflagellate cysts assemblages from the clay intercalation of the topmost part of the gypsum sequence in the Babczyn 2 borehole (SE Poland; Fig. 2). These assemblages indicate marine invasion into the Central Paratethys prior to the termination of the evaporite stage that occurred $13.36 \mathrm{Ma}$ when the Central Paratethys returned to open-marine conditions, and the Eastern Paratethys remained more brackish (Simon et al. 2019).

\section{Geological setting}

Badenian sulphate deposits occur in most of the northern and northeastern Carpathian Foredeep Basin from Moravia in Czech Republic in the west through southern Poland and western Ukraine to the Ukrainian-Romanian borderland and Moldova (Peryt 2006, 2013b). Sulphate deposits in southeastern Poland consist of a sequence of lithofacies grouped into 18 lithostratigraphic units (from 'a' to ' $r$ '; Kasprzyk 1993) or seven lithosomes (from 'A' to 'G'; Kubica 1992, 1994; Bąbel 2005). In SE Poland, in the Lubaczów area located close to the Polish-Ukrainian border (Fig. 2), the primary gypsum is partly or completely replaced by anhydrite and secondary gypsum (Kasprzyk 1995). In the Cieszanów 1 borehole, units 'a'-'o' have a total thickness of $44.8 \mathrm{~m}$ (Kasprzyk 1995), and in the Babczyn 2 borehole the gypsum sequence (32 $\mathrm{m}$ thick, depth 409-441 m) consists of units 'a'-'l' and ' $m$ '-'o' (the upper part of the sequence is shown in Fig. 2, after Peryt and Kasprzyk 1992). Unit ' $m$ ' is composed 

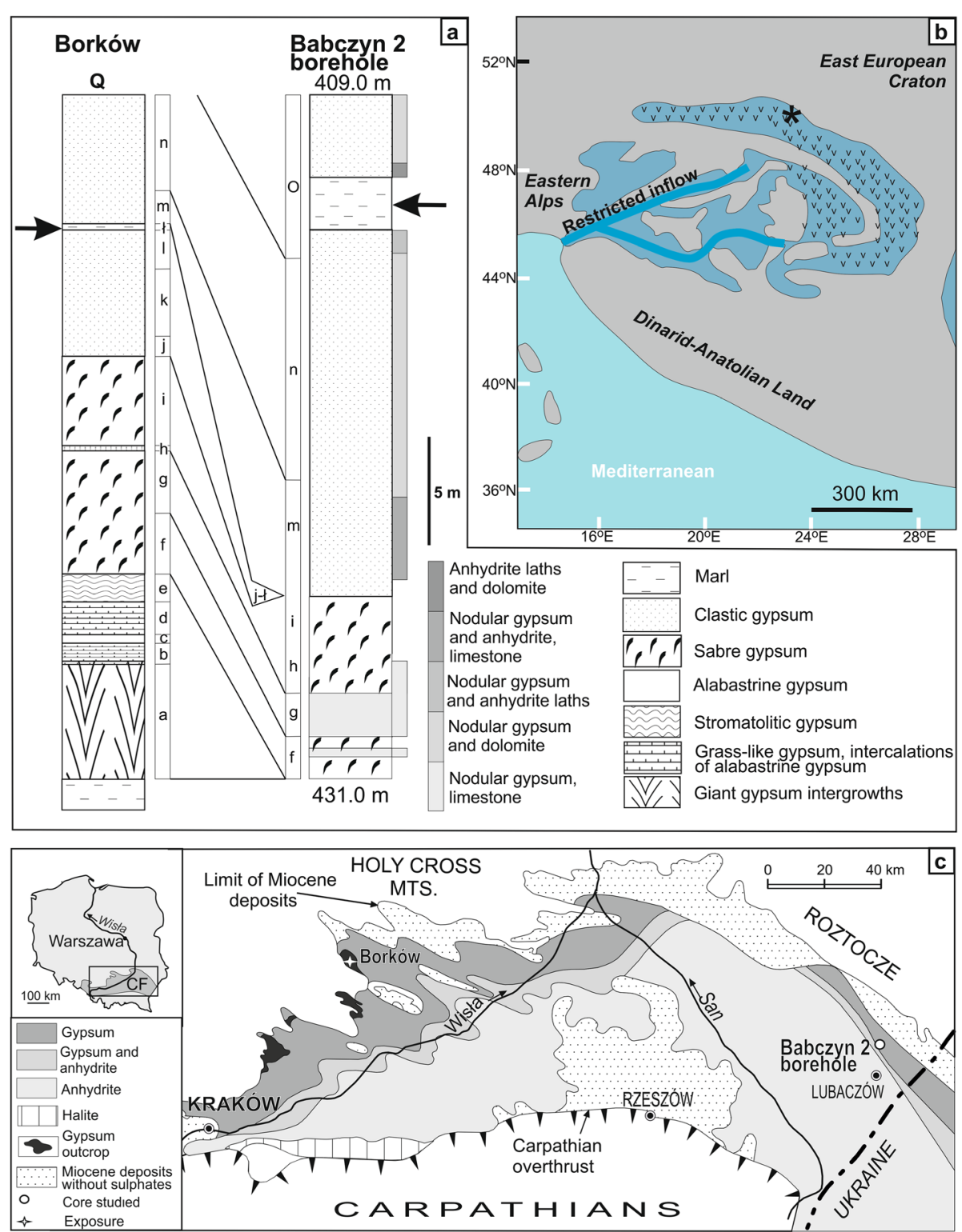

Fig. 2 Geological setting. a Sections of Badenian gypsum of the Borków quarry (after Peryt and Jasionowski 1994) and Babczyn 2 borehole (middle and upper parts, after Peryt and Kasprzyk 1992; lower part is not shown); black arrows show the intercalations of microfossils-bearing clays described by Peryt (2013a) and this paper, respectively; alabastrine gypsum - alabastrine gypsum originated due to recrystallization of finegrained gypsum precipitated in association with microbial mats (cf. Orti Cabo et al. 1984) and then transported during storms (cf. Kwiatkowski 1972); sabre gypsum - gypsum type composed of curved gypsum crystals resembling sabres which grew upwards and simultaneously curved laterally, thus most crystals are inclined and curved in the same direction (Bąbel 1986); b Simplified palaeogeographic reconstruction of Mediterranean-Paratethys connection during Badenian Salinity Crisis interval (modified after de Leeuw et al. 2010); star marks location of the Babczyn 2 borehole; c Location map of the Babczyn 2 borehole (after Peryt and Kasprzyk 1992) and the sulphate lithofacies of the Polish Carpathian Foredeep (after Kasprzyk 2005 and Bukowski 2011: fig. 10)

of laminated and bedded microcrystalline gypsum that contains layers and irregular bodies of gypsiferous, occasionally brecciated, microbial-peloidal carbonate, while unit ' $n$ ' consists of thinly laminated gypsum with three beds of carbonate-gypsum breccias in the middle part. Unit 'o' is nodular gypsum intercalated by a $2.3 \mathrm{~m}$ layer of marly clays (depth: $413-415.3 \mathrm{~m}$ ) rich in plant remains and carbonate lithoclasts (Pawłowska and Kubica: Karta otworu wiertniczego Babczyn 2, unpublished) as well as crushed mollusc (Modiolus?) shell fragments (Śliwiński et al. 2012). Interpretation by Peryt and Kasprzyk (1992) assumed that, following a sea-level drop after the deposition of unit ' $n$ ', very shallow subaqueous and subaerial conditions prevailed during deposition of 
unit 'o' (Peryt and Kasprzyk 1992). Accordingly, this marly clay is younger than unit ' $\mathrm{Y}$ ' in which Peryt (2013a), in the Borków quarry section (Fig. 2), recorded previously the benthic foraminifer assemblages composed of pioneer, opportunistic, r-selected species dominated by elphidiids.

\section{Material and methods}

For the foraminiferal study, all samples of approximately $200 \mathrm{~g}$ were disaggregated in Glauber's salt, cleaned in an ultrasonic bath, dried and sieved into $\mathrm{a} \geq 63 \mu \mathrm{m}$ size fraction. An aliquot of about 200-300 specimens of foraminifers was picked for the faunal analysis. The classification scheme used follows Loeblich Jr. and Tappan (1987), Cicha et al. (1998), Pawlowski et al. (2013) and Dubicka (2019). The palaeoenvironmental interpretation was based on foraminifers and the requirements of present-day representatives of recorded taxa (e.g. Walton and Sloan 1990; Verhallen 1991; Murray 1991, 2006; Jorissen et al. 1992; Sen Gupta and Machain-Castillo 1993; Kaiho 1994; Hayward et al. 1997; Loubere 1997; Alve and Murray 1999; Bernard and Sen Gupta 1999; Vaniček et al. 2000; Buzas-Stephens et al. 2003; Fiorini 2004; Kouvenhoven and van der Zwaan 2006; Debeney et al. 2009; Kaminski 2012; Schiebel and Hemleben 2017). The figured specimens are deposited in the Institute of Paleobiology, Polish Academy of Sciences, Warszawa (ZPAL F. 68).

The samples for the palynological study were processed following the procedure including 38\% hydrochloric acid $(\mathrm{HCl})$ dissolution, $40 \%$ hydrofluoric acid (HF) dissolution, heavy liquid $\left(\mathrm{ZnCl}_{2}+\mathrm{HCl}\right.$; density $2.0 \mathrm{~g} / \mathrm{cm}^{3}$ ) separation, and sieving at $15 \mu \mathrm{m}$ on a nylon mesh in ultrasounds for $10-15 \mathrm{~s}$. No oxidation in nitric acid $\left(\mathrm{HNO}_{3}\right.$, fuming) was applied. The quantity of each rock sample processed was $10 \mathrm{~g}$. Two slides from each sample were made using glycerine jelly as a mounting medium. Dinoflagellate cysts were qualitatively determined up to 300 specimens using a Zeiss Axiolab microscope; the remaining specimens were scanned for their taxonomy only. Palynofacies for each sample were calculated based on 500 particles. The unprocessed rock samples, palynological residues and slides are stored in the collection of the Institute of Geological Sciences, Polish Academy of Sciences, Research Centre in Kraków.

\section{Results}

Low-diversity foraminiferal assemblages are recorded in the interval studied (Table 1; Figs. 3, 4 and 5). Their preservation is poor to moderate. Foraminiferal tests are mostly recrystallized and often broken. The benthic foraminiferal assemblages consist entirely of calcareous species of very small and tiny tests. They are dominated by
3 taxa, i.e. Nonion parvus, Haynesina depressula and Ammonia spp. (mainly A. parkinsoniana; also common transitional forms from parkinsoniana to tepida and $A$. tepida). They form $60 \%$ to $80 \%$ of the assemblages (Fig. 6). Elphidium spp. is also a common and persistent contributor to the assemblages (6\%-20\%). Minor components are Rosalina obtusa and hauerinids (Quinqueloculina sp., Triloculina sp., Pseudotriloculina consobrina, and Sigmoilinita tenuis) forming up to 5\% of the assemblages. Nonion parvus and Ammonia spp. fluctuate significantly throughout the interval. Relative abundance of Ammonia spp. varies between $6 \%$ and $62 \%$; Nonion parvus accounts for $9 \%$ to $64 \%$. Foraminiferal assemblages from samples 2 and 4 represent near-monospecific faunas (Hayward 2014). In sample 2, Ammonia spp. makes $62 \%$ of the assemblage; other components do not exceed $10 \%$ each. In sample 4, Nonion parvus makes up $64 \%$ of the assemblage, while the contribution of Ammonia spp. drops to $6 \%$ (Fig. 6).

The species show small sizes compared to usual dimensions. Planktonic foraminifera are scarce. They are represented mainly by small-sized Globigerina (G. tarchanensis), Trilobatus (T. altospiralis), Globoturborotalita cf. druryi, Tenuitellinata sp. Redeposited Eocene and Cretaceous foraminifers are quite common.

The 2.3-m-thick layer of marly clays yielded high amounts of palynological organic matter composed chiefly of terrestrial elements - mainly dark brown and black phytoclasts and pollen grains, the proportions of which oscillate between $80 \%$ and $90 \%$. Marine elements that are present throughout the whole interval - dinoflagellate cysts, other algae and subordinate foraminifera organic linings, are up to a few per cent. Amorphous organic matter $(\mathrm{AOM})$ is also present in the whole interval; except for sample 3, where it does not exceed $10 \%$ (Fig. 6).

Dinoflagellate cysts are well to moderately preserved, being all light-coloured (Table 1; Figs. 7, 8 and 9). Their assemblages are dominated by three taxa: Spiniferites (mainly S. ramosus), Operculodinium and Systematophora placacantha (Table 2). Proportions of these taxa fluctuate slightly, but generally Spiniferites is most common in all these samples; Systematophora placacantha is most frequent in basal samples, and becomes rarer in the upper part of the interval. They are accompanied by subordinate Lingulodinium machaerophorum, Pentadinium laticinctum, Labyrinthodinium truncatum, Melitasphaeridium choanophorum and Pyxidiniopsis. A characteristic feature of the dinoflagellate cyst assemblages is almost complete lack of peridinioids. There are no Palaeocystodinium (known from older Badenian strata of the Carpathian Foredeep). Rare specimens of Lejeunecysta may be reworked. 
Table 1 Identified taxa (asterisked are reworked species)

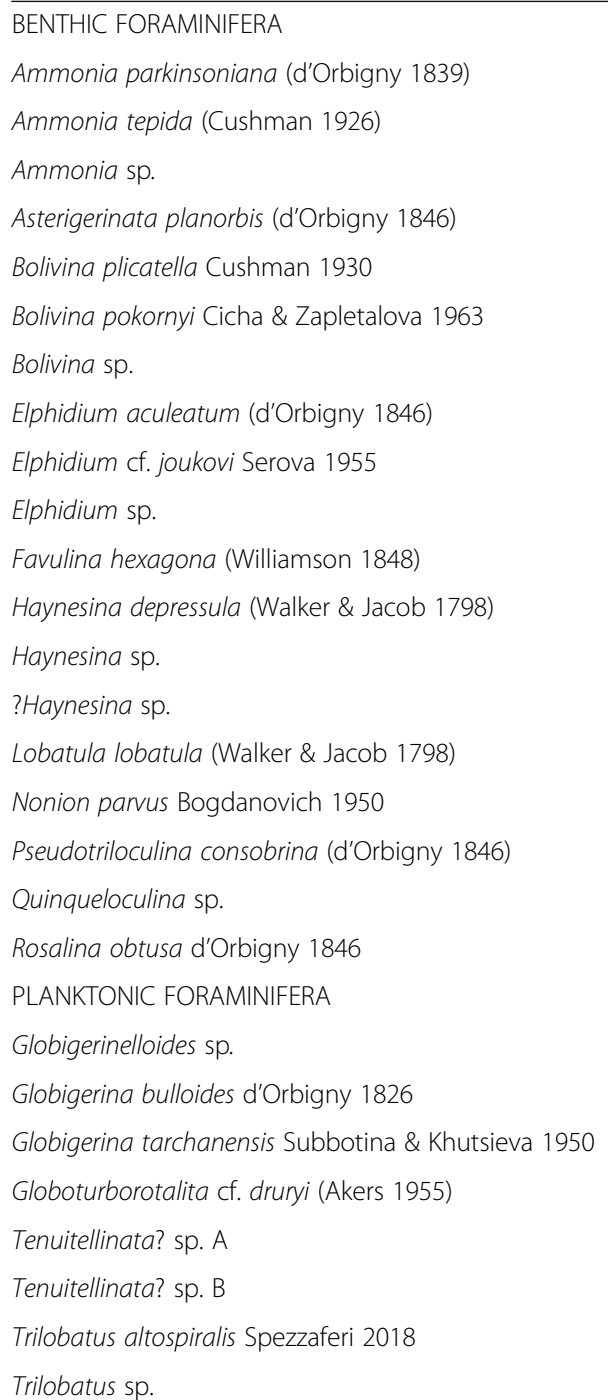

Table 1 Identified taxa (asterisked are reworked species) (Continued)

Dinogymnium sp.*

Enneadocysta arcuata* (Eaton 1971) Stover \& Williams 1995

Enneadocysta sp.*

Florentinia sp.*

Glaphyrocysta semitecta* (Bujak in Bujak et al. 1980) Lentin et Williams 1981

Glaphyrocysta sp.*

Homotryblium abbreviatum* Eaton 1976

Homotryblium floripes* (Deflandre \& Cookson 1955) Stover 1975

Homotryblium plectilum* Drugg \& Loeblich Jr. 1967

Homotryblium tenuispinosum* Davey \& Williams 1966

Hystrichokolpoma spp.

Hystrichosphaeropsis obscura Habib 1972

Impagidinium? aculeatum (Wall 1967) Lentin \& Williams 1981

Impagidinium spp.

Labyrinthodinium truncatum Piasecki 1980

Lejeunecysta spp.

Lingulodinium machaerophorum (Deflandre \& Cookson 1955) Wall 1967

Melitasphaeridium choanophorum (Deflandre \& Cookson 1955) Harland \& Hill 1979

Melitasphaeridium? pseudorecurvatum (Morgenroth 1966) Bujak et al. 1980

Nematosphaeropsis sp.

Operculodinium centrocarpum (Deflandre \& Cookson 1955) Wall 1967

Operculodinium spp.

Palynodinium grallator* Gocht 1970

Pentadinium laticinctum Gerlach 1961

Pentadinium sp.

Pyxidinopsis psilata Wall \& Dale 1973

Pyxidinopsis? sp.

Reticulatosphaera actinocoronata (Benedek 1972) Bujak \& Matsuoka 1986 Rottnestia borussica* (Eisenack 1954) Cookson \& Eisenack 1961

Spiniferites pseudofurcatus (Klumpp 1953) Sarjeant 1970

Spiniferites ramosus (Ehrenberg 1838) Mantell 1854

Spiniferites spp.

Surculosphaeridium sp.*

Systematophora placacantha (Deflandre \& Cookson 1955) Davey et al. 1969

Tanyosphaeridium sp.*

Wetzeliella sp.*

Gen. et spec. Indet.

\section{ACRITARCHS}

Svenkodinium sp. (acritarch)

Veryhachium sp. (acritarch) 


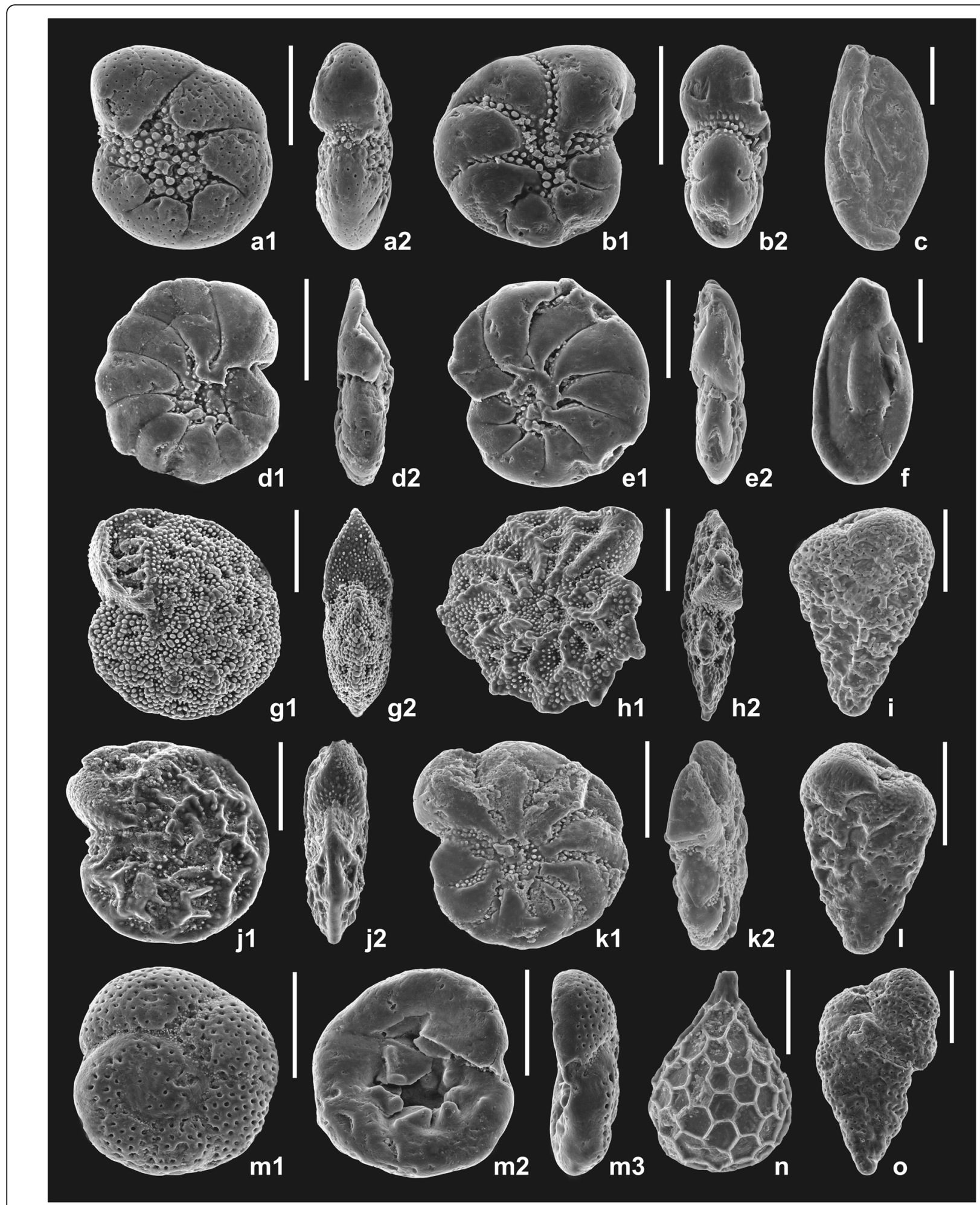

Fig. 3 Benthic foraminifers from the Babczyn 2 borehole. a, b Nonion parvus; c Quinqueloculina sp.; d, e Haynesina depressula; f Pseudotriloculina consobrina; $\mathbf{g}$ Elphidium cf. joukovi; $\mathbf{h}$ Elphidium aculeatum; i Bolivina plicatella; j Elphidium sp. (sample 2/4); k? Haynesina sp.; $\mathbf{I}$ Bolivina sp.; $\mathbf{m}$ Rosalina obtusa; $\mathbf{n}$ Favulina hexagona; o Bolivina pokornyi. Scale bar $=100 \mu \mathrm{m} ; \mathbf{a}-\mathbf{e}, \mathbf{g}-\mathbf{h}, \mathbf{m}$ : Sample 1; f: Sample 6; i, k-I: Sample 3; j, n-o: Sample 4 


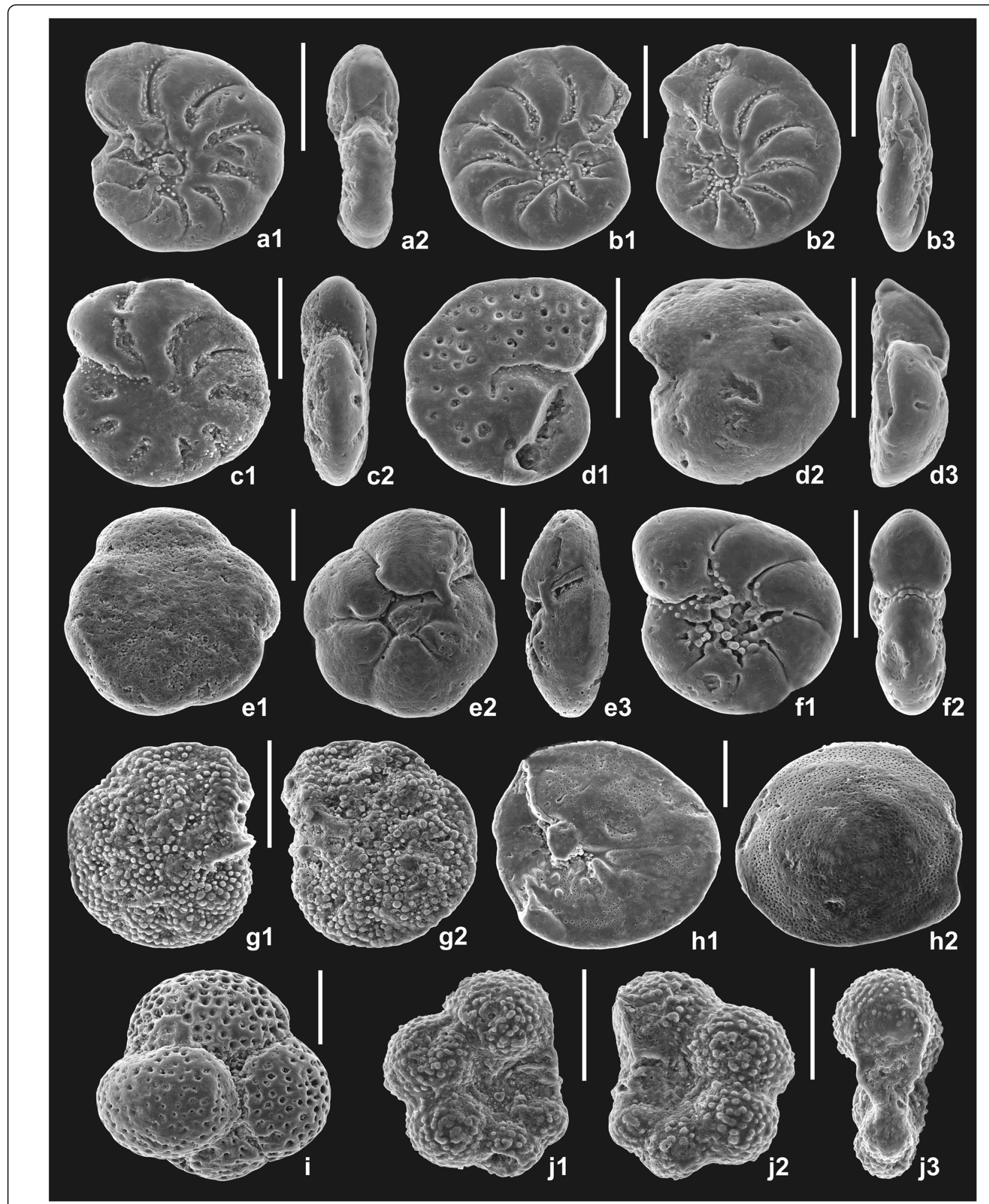

Fig. 4 Benthic and planktonic foraminifers from the Babczyn 2 borehole. a, b Haynesina depressula; c Haynesina sp.; d Lobatula lobatula; e Ammonia sp. (transitional from parkinsoniana to tepida); f Nonion parvus; $\mathbf{g}$ Elphidium sp.; $\mathbf{h}$ Asterigerinata planorbis; i Globoturborotalita cf. druryi; $\mathbf{j}$ Globigerinelloides sp. (Cretaceous form). Scale bar $=100 \mu$ m; a, d, f, g, j: Sample 5; b, e, h, i: Sample 6; c: Sample 7 


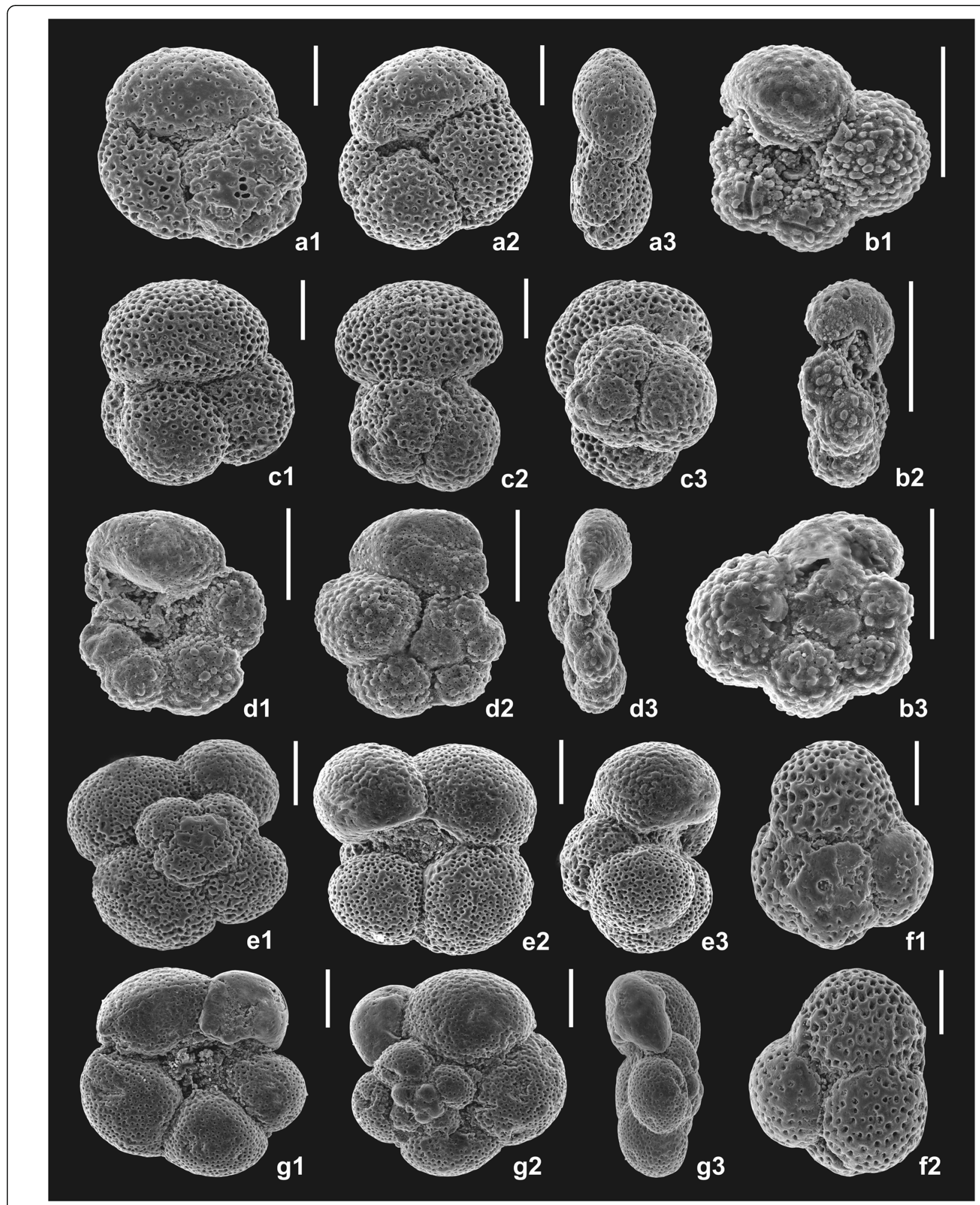

Fig. 5 Planktonic foraminifers from the Babczyn 2 borehole. a Trilobatus sp.; b Tenuitellinata? sp. A; c Trilobatus altospiralis; d Tenuitellinata? sp. B; e Globigerina bulloides; f Globoturborotalita cf. druryi; $\mathbf{g}$ Globigerina tarchanensis. Scale bar = 100 um; a, e-g: Sample 6; b, d: Sample 1; c: Sample 3 


\section{FORAMINIFERS}

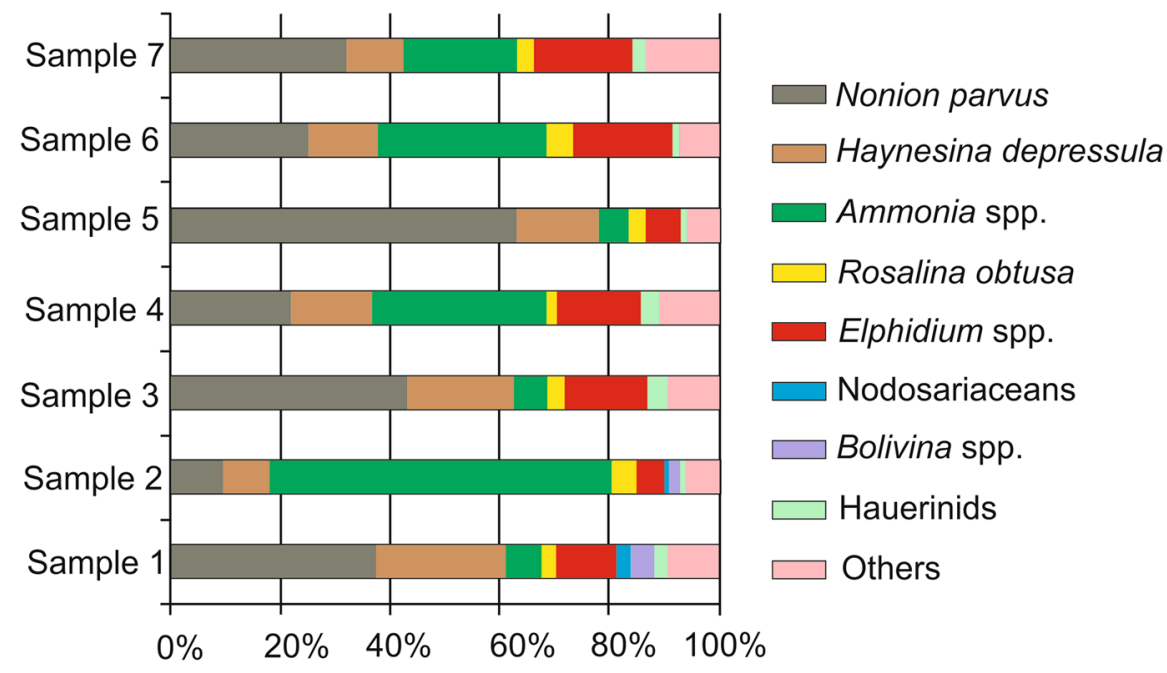

\section{PALYNOFACIES}

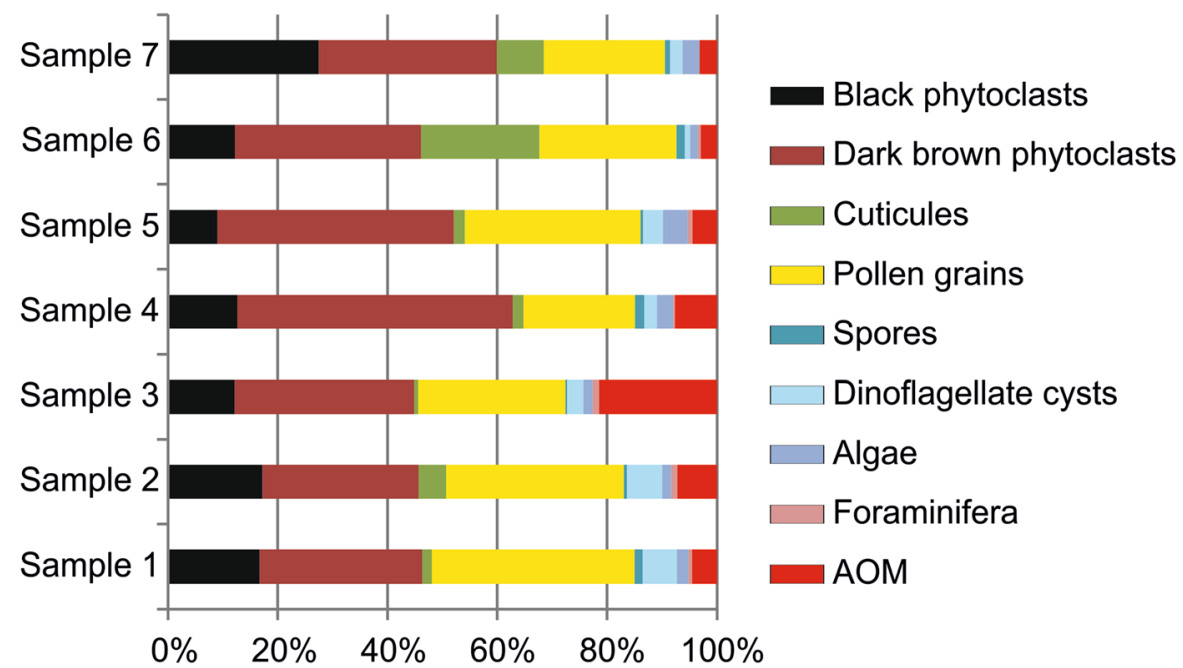

Fig. 6 Relative abundances of dominant and common foraminifer species or groups of foraminifer species in the Babczyn 2 borehole interval studied (above) and corresponding palynofacies changes (below). AOM = Amorphous organic matter

\section{Interpretation}

The presence of marine palynomorphs (dinoflagellate cysts) and foraminifera suggests a marine environment during deposition of the interval in question. Interestingly, the material contains very rare Leiosphaeridia, a prasinophycean genus (see e.g. Guy-Ohlson 1996) that commonly occurs in the Miocene of the Carpathian Foredeep, accumulated in stress environments associated with increased salinity (e.g. Gedl 2016). Moreover, the dinoflagellate cyst assemblages lack Polysphaeridium, another indicator of increased (e.g. Bradford and Wall 1984) or decreased salinity (Edwards and Andrle 1992).
Frequent occurrence of this genus was reported from strata that followed the middle Miocene Badenian Salinity Crisis (e.g. Gedl and Peryt 2011; Peryt et al. 2014; Gedl 2016; Gedl et al. 2016). Preceding strata, in contrast, yielded no Polysphaeridium or rare specimens of this genus (e.g. Peryt and Gedl 2010).

Dominant taxa in the benthic foraminiferal assemblages of the interval, i.e. Nonion parvus, Haynesina depressula and Ammonia spp., represent shallow infaunally living species, preferring muddy or clayey substrate for thriving, tolerant of suboxic environments, brackish to normal marine salinity, and inner shelf depths 

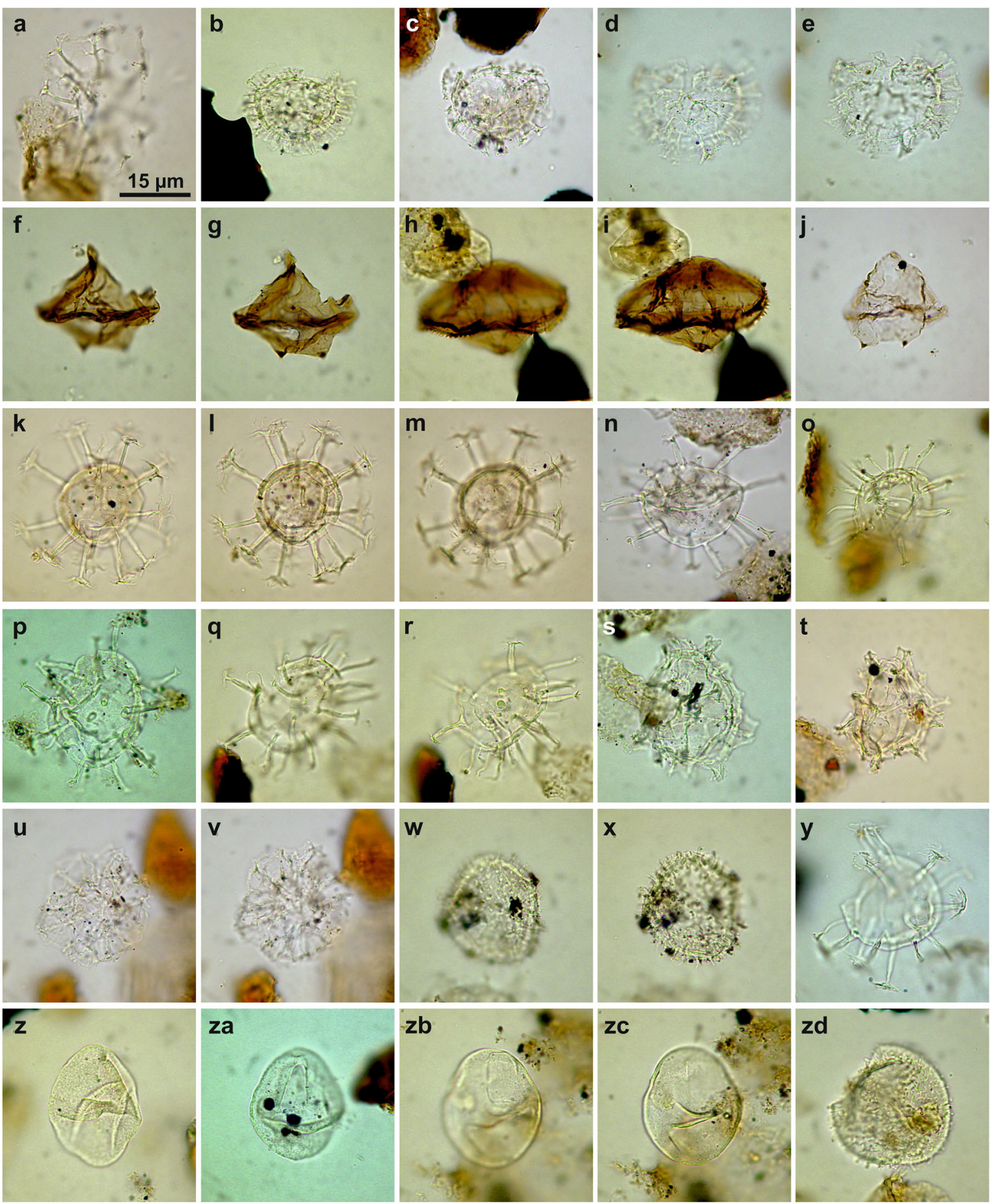

za
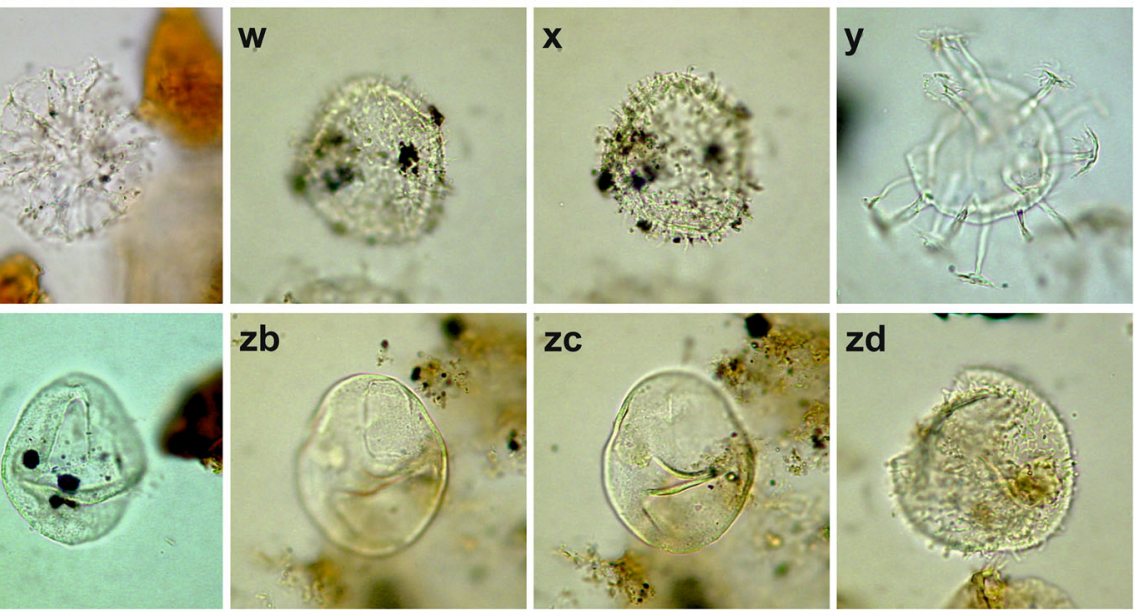

Fig. 7 Dinoflagellate cysts from the Babczyn 2 borehole (scale bar in a refers to all other photomicrographs; photo by P. Gedl). a Reticulatosphaera actinocoronata; b Labirynthodinium truncatum; c Labirynthodinium truncatum; d, e Labirynthodinium truncatum (same specimen, various foci); $\mathbf{f}, \mathbf{g}$ Lejeunecysta sp. (same specimen, various foci); $\mathbf{h}$, i Lejeunecysta sp. (same specimen, various foci); $\mathbf{j}$ Lejeunecysta sp.; k-m Melitasphaeridium choanophorum (same specimen, various foci); $\mathbf{n}$ Melitasphaeridium?pseudorecurvatum; o Melitasphaeridium?pseudorecurvatum; $\mathbf{p}$ Melitasphaeridium?pseudorecurvatum; q, $\mathbf{r}$ Melitasphaeridium?pseudorecurvatum (same specimen, various foci); $\mathbf{s}$ Impagidinium?aculeatum; $\mathbf{t}$ Impagidinium?aculeatum; u, v Nematosphaeropsis sp. (same specimen, various foci); w, x Operculodinium? sp. (same specimen, various foci); $\mathbf{y}$ Melitasphaeridium choanophorum; $\mathbf{z}$ Pyxidinopsis psilata; za Pyxidinopsis psilata; zb, zc Pyxidinopsis psilata (same specimen, various foci); zd Gen. et spec. Indet. a: Sample 7; b, d, e, s, y: Sample 1; c, j: Sample 4; $\mathbf{f}$, g: Sample 5; h, i, n, o, u, v, z, zb-zd: Sample 3; k-m, t: Sample 6; p-r, w, x, za: Sample 2 

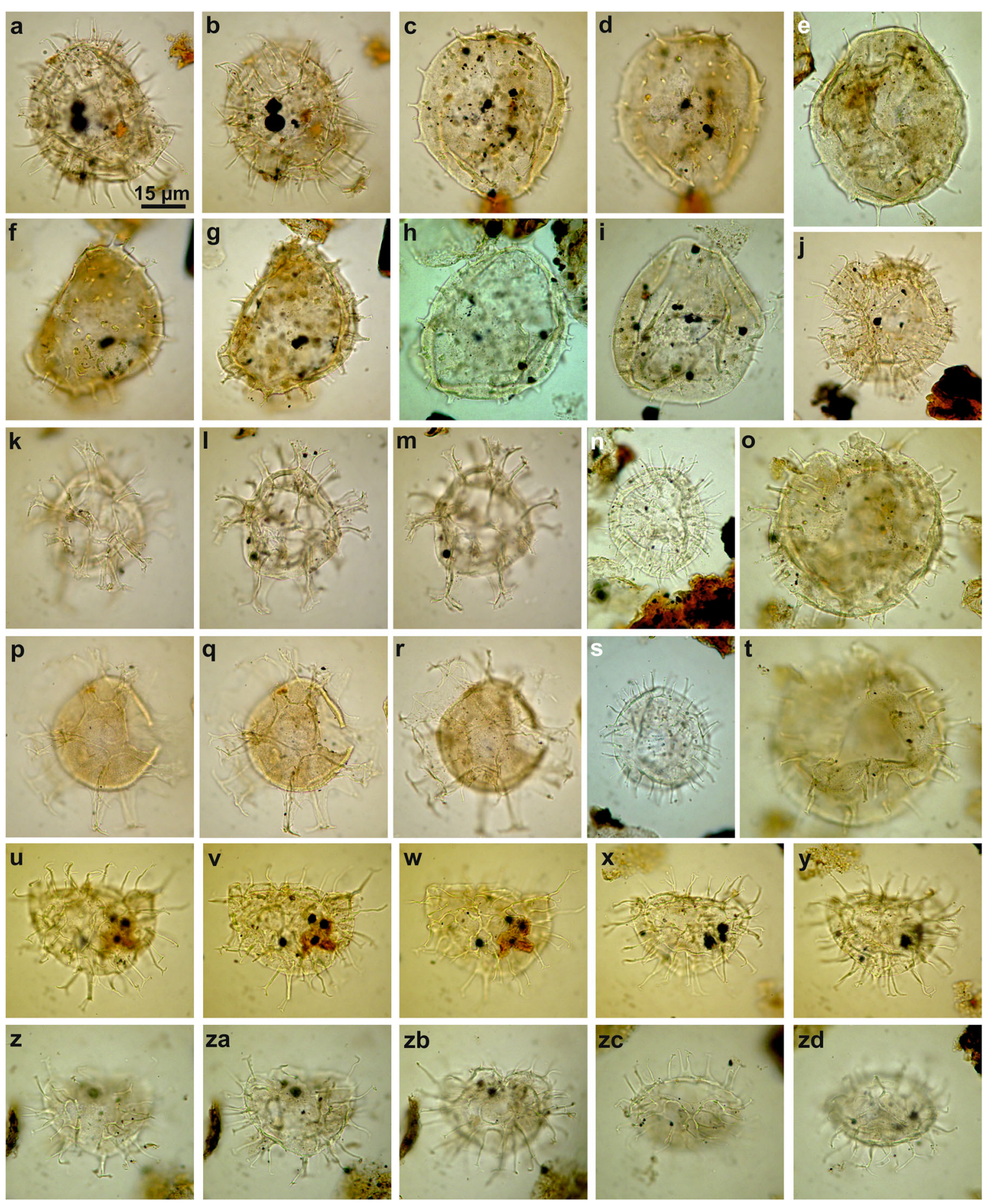

Fig. 8 Dinoflagellate cysts from the Babczyn 2 borehole (scale bar in a refers to all other photomicrographs; photo by P. Gedl). a, b Operculodinium centrocarpum (same specimen, various foci); c, d Operculodinium sp. A, intermediate form to $O$. sp. B (same specimen, various foci); e Operculodinium centrocarpum, large morphotype with relatively short and sparse processes; $\mathbf{f}$, g Operculodinium sp. A (same specimen, various foci); $\mathbf{h}$ Operculodinium sp. B; i Operculodinium sp. B; j Operculodinium centrocarpum; $\mathbf{k}-\mathbf{m}$ Spiniferites pseudofurcatus (same specimen, various foci); $\mathbf{n}$ Operculodinium centrocarpum; o, t Operculodinium centrocarpum, large morphotype with relatively short and sparse processes (same specimen, various foci); $\mathbf{p}-\mathbf{r}$ Spiniferites sp., morphotype with high parasutural ridges (same specimen, various foci; $\mathbf{s}$ Operculodinium centrocarpum, small morphotype with smooth cyst wall; $\mathbf{u}-\mathbf{w}$ Systematophora placacantha (same specimen, various foci); $\mathbf{x}, \mathbf{y}$ Systematophora placacantha, morphotype with reduced proximal ridges, similar to $S$. ancyrea (same specimen, various foci); z-zb Systematophora placacantha (same specimen, various foci); zc, zd Systematophora placacantha (same specimen, various foci). a, b, k-m, p-r: Sample 7; c-e, j: Sample 6; f, g, x y: Sample 4; h, i, $\mathbf{n}$ : Sample 2; o, t, z-zd: Sample 3; s: Sample 1; u-w: Sample 5 

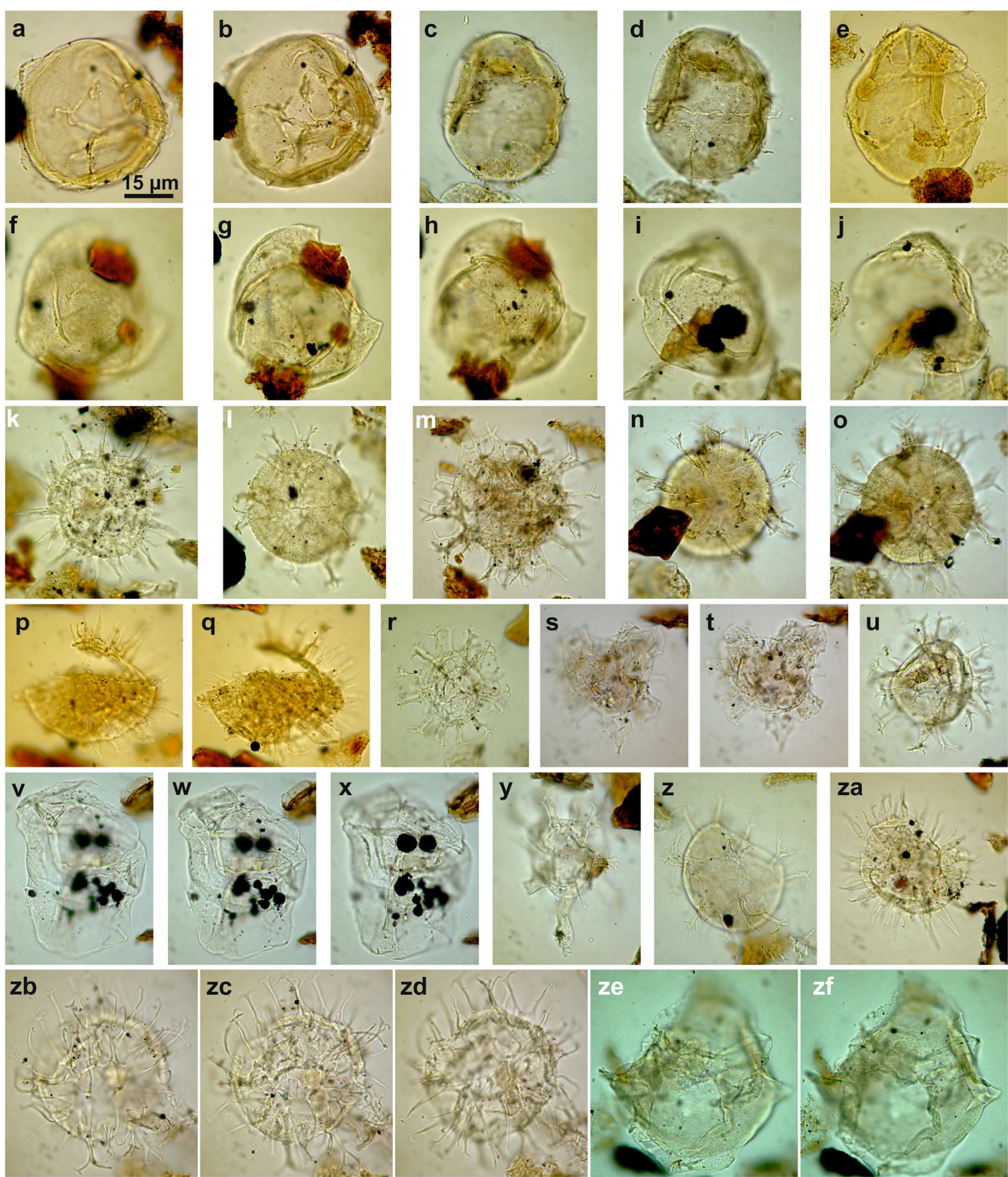

Fig. 9 Dinoflagellate cysts from the Babczyn 2 borehole (scale bar in a refers to all other photomicrographs; photo by P. Gedl). a, b Pentadinium sp., species with reduced periphragmal ridges (same specimen, various foci); $\mathbf{c}$, d Pentadinium sp. (same specimen, various foci); e Pentadinium sp.; $\mathbf{f}-\mathbf{h}$ Pyxidinopsis? sp., large species devoid of any parasutural features except for $1 \mathrm{P}$ archaeopyle (same specimen, various foci); $\mathbf{i}, \mathbf{j}$ Pyxidinopsis? sp. (same specimen, various foci); $\mathbf{k}$ Lingulodinium machaerophorum; I Spiniferites sp., species with thick, spongy cyst wall; $\mathbf{m}$ Spiniferites sp.; $\mathbf{n}$, o Spiniferites sp., species with thick, spongy cyst wall (same specimen, various foci); $\mathbf{p}, \mathbf{q}$ Lingulodinium machaerophorum, specimen with 5P archaeople (same specimen, various foci); $\mathbf{r}$ Spiniferites ramosus; s, t Hystrichokolpoma sp. (same specimen, various foci); u Spiniferites ramosus; v-x Hystrichosphaeropsis obscura, specimen with granular endophragm, and periphragm bearing small, irregularly distributed spines on hypocyst (same specimen, various foci); y Hystrichokolpoma sp.; z Achomosphaera sp.; za Lingulodinium machaerophorum; zb-zd Systematophora placacantha, complete specimen with operculum, disruption suture visible in $\mathbf{z d}$ (same specimen, various foci); ze, zf Pentadinium laticinctum (same specimen, various foci). a-d, z: Sample 6; e: Sample 5; f-l: Sample 3; $\mathbf{m}-\mathbf{q}, \mathbf{s}-\mathbf{u}$, za: Sample 4; r, v-y: Sample 1; zb-zf: Sample 2 
Table 2 Distribution of dinoflagellate cysts and acritarchs (asterisked are reworked species). x - Appearance of a taxon beyond the count. Total count includes taxa presumed to be in situ only

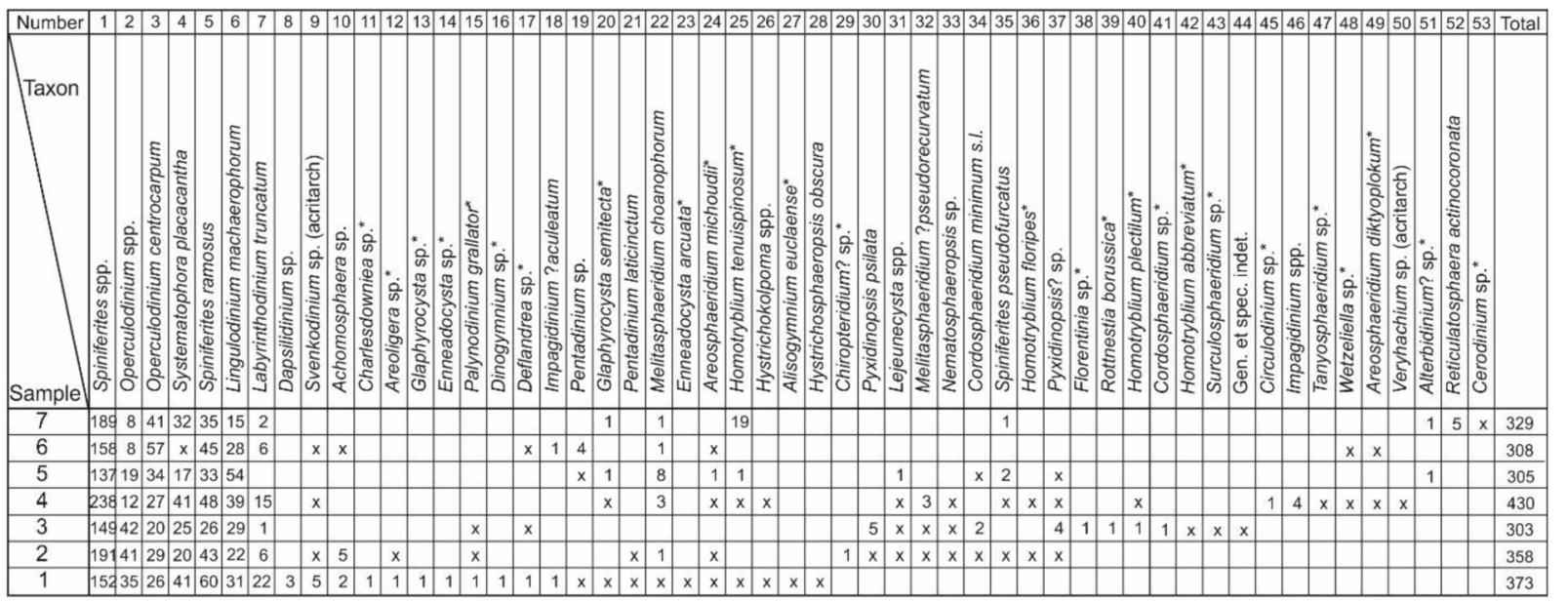

(Richter 1964; Zaninetti 1982; Murray 1991, 2006; Alve and Murray 1999). Elphidium spp., Rosalina obtusa and hauerinids, common in the material, are epifaunally living species preferring well-oxygenated environments (Langer 1993; Hayward et al. 1997; Alve and Murray 1999). Deep infaunally living foraminifers, indicators of dysoxic environments, are not recorded in the material.

Taxonomically impoverished foraminiferal assemblages, dominated by a few species with very small sizes, indicate adverse environmental conditions (e.g. Bernard 1986; Murray 1991, 2006; Sen Gupta and MachainCastillo 1993; Hayward et al. 1997).

Nonionids, represented in the material by Nonion parvus and Haynesina depressula, are infaunal organisms, widespread in marginal marine environments, common in sediments with highly variable mud and total organic carbon (TOC) contents (Murray 1968, 2006; Alve and Murray 1999; Vaniček et al. 2000). Haynesina tolerates lower salinity $(0-30 \%)$, while Nonion prefers normal marine salinity (Murray 1991). Ammonia, an opportunistic genus widespread in marginal marine environments worldwide (Walton and Sloan 1990; Murray 1991, 2006; Buzas-Stephens et al. 2003), is common in sediments with highly variable mud and TOC contents and able to tolerate low oxygen for several days (Moodley and Hess 1992; Murray 2006). The genus is represented, in the material, by A. parkinsoniana and $A$. tepida with common transitional forms. Their environmental requirements are quite well-recognized, which enables to interpret environmental changes. The two species - common to abundant in the foraminiferal assemblages - are well adapted to salinitystressed conditions (Fiorini 2004).

Assemblages dominated by the two species are characteristic of environments strongly influenced by fluvial waters. A. tepida is a typical species of river-dominated shelves, benefited from a noticeable input of riverine phytodetritus to the sediment and the most tolerant for high organic matter supply (Debeney et al. 2009). The significant changes in relative abundance in the Ammonia spp. group throughout the interval may indicate changes in salinity and oxygenation of bottom waters.

The benthic foraminiferal assemblages in the interval are dominated by a few infaunal species preferring muddy or clayey substrate for living, brackish to normal marine salinity, and inner shelf depths. Planktonic foraminifera recorded in the material are indicators of shallow and cool water (Bicchi et al. 2003). However, their scarcity in the material studied may indicate that they did not live there but they were transported by waves from deeper part of the sea. Shallow, cool water with slightly lowered oxygenation at the bottom and a slightly hyposaline to normal salinity marine environment is thus concluded for the foraminiferal assemblage from the marly intercalation in the Badenian gypsum.

No indications of salinity fluctuations have been recorded throughout the interval. Although the predominance of terrestrial elements in the composition of dinoflagellate cysts points to an intense influx from neighbouring land, pollen grains could be airborne. Higher proportions of cuticles (samples from the upper part of succession), especially large-sized, can be associated with source proximity and/or increased intensity of terrestrial input. However, freshwater algae occur in none of these samples. Lack of peridinioids commonly associated with nutrient-rich estuarian or upwelling environments additionally excludes freshwater input and points rather at oligotrophic conditions in the water column (photic zone). 


\section{Discussion}

As the Badenian evaporite basin was located in a depression in which the brine top level occurred below the contemporaneous sea level, it could be subject to rapid flooding when the sea level rose or when the physical barrier blocking this basin from the Tethys/Paratethys reservoir was temporarily removed (Peryt 2006). The connection of the Carpathian Foredeep Basin with the marine reservoir was short-lived. After such environmental change, benthic foraminifers started to colonize a new, previously defaunated niche, and the pattern of benthic foraminiferal colonization is similar in each case to that related to the reflooding terminating the Badenian Salinity Crisis (cf. Szczechura 2000; Peryt and Peryt 2009; Gedl and Peryt 2011). This refers in particular to the poorly diversified, small and strongly abraded foraminifera occurring just above the gypsum in the Jamnica S-119 borehole section (located some $100 \mathrm{~km} \mathrm{WNW} \mathrm{of}$ the Babczyn 2 borehole) and described by Szczechura (2000). She concluded that a dominance of infaunal elements in the assemblage, as well as the state of preservation of the tests and their low diversity, indicates oxygen-deficient conditions and/or insufficient $\mathrm{CaCO}_{3}$ saturation. Peryt et al. (2004) recorded an impoverished foraminiferal assemblage dominated by Nonion and Haynesina from siliciclastic deposits, overlying gypsum deposits, of the Ptashkino section (East Crimea, Ukraine). They interpreted this assemblage as typical for a shallow water marsh or lagoon environment with a decreased salinity. Thus, it seems that the foraminiferal assemblage of the Babczyn 2 borehole represents a typical late Badenian pioneer, colonizing assemblage. Palynofacies and dinocysts from Jamnica S-119 borehole (Gedl 1999) and Babczyn 2 borehole also show similarities. In Jamnica S-119 borehole, continental elements dominate the assemblages coming from the lower part, and marine elements (dinocysts) start to be more common above it. The dinocysts assemblages are also similar in both sections - they are characterized by lack of Polysphaeridium. Leiosphaeridia appears in Jamnica S-119 borehole in the sample from the depth interval of $257-258 \mathrm{~m}$, but its more common occurrence was noted in the sample from the depth of $255-256 \mathrm{~m}$ (Gedl 1999), which is a counterpart of samples from the upper part of the Babczyn 2 borehole clay intercalation in gypsum.

The marly clay intercalation of the Babczyn 2 borehole intercalation, containing crushed mollusc (Modiolus?) shell fragments, was previously interpreted by Śliwiński et al. (2012) as karst cavity infilling. The middle Miocene karstification of Badenian gypsum deposits of the Carpathian Foredeep occurred in two phases: soon after gypsum deposition and then after deposition of the lower series of the Pecten clays with Neobulimina longa (see Osmólski 1976, with references therein). However, there is no proof that the marly clays in the uppermost part of the gypsum sequence of the Babczyn 2 borehole represent karst cavity infilling. The composition of the micropalaeontological assemblages differs both from those recorded in the strata overlying gypsum deposits at Shchyrets (Peryt et al. 2014) and from the assemblages of the Pecten beds in the Babczyn 2 borehole.

It remains enigmatic, however, why no such intercalations of marine clays have been reported from elsewhere. One possible explanation is that the upper parts of the gypsum sequence have been eroded prior to the onset of deposition of the Late Badenian Ratyn Limestone and/or marine clays. In the final stages of the Badenian Salinity Crisis, gypsum beds that previously accumulated along the basin margins became then exposed, leading to reworking of clastic gypsum into the deeper basin (Kasprzyk 1993; Peryt 1996, 2000; de Leeuw et al. 2018). As the result, the marine facies of the Ratyn Limestone in western Ukraine overlies various gypsum units (even the equivalent of unit ' $\mathrm{e}$ ' in southern Poland - see Peryt 1996: Fig. 4). Consequently, it is probable that the intercalations of marine clays escaped from the erosion in few cases only (e.g., clays deposited in local depressions). In addition, the Pecten Beds bear intercalations of clastic gypsum and this indicates a partial erosion of the marginal gypsum before and during deposition of these strata (Śliwiński et al. 2012).

\section{Implications}

The marine salina model is successfully applied for the Fore-Carpathian Basin (Peryt 2001, 2006, 2013b; Bąbel 2004, 2007; Cendón et al. 2004). It assumes that the Badenian evaporite basin was located in a depression in which the brine top level occurred below the contemporaneous sea level, and it was supplied with seawater seeping through a barrier that separated the basin from the sea or overflowing it occasionally in the form of short-lived marine transgressions. Consequently, it was in fact a saline lake supplied with marine water (Bąbel 2007) as far as the Polish and Ukrainian parts of the basin are concerned. Sedimentary history of the Badenian gypsum suggests two major salinity rises (and hence two saline cyclothems were recognized in the Carpathian Foredeep Basin - see Bąbel 1999b, with references therein) and several marine influxes causing partial reworking and/or dissolution of pre-existing gypsum (Kasprzyk 1999, with discussion therein).

As discussed by de Leeuw et al. (2018), global sealevel generally remained low during the Badenian Salinity Crisis although some of the modelled short-term global highstands may have temporarily increased the connectivity of the Central Paratethys with the global ocean, leading to a decrease in its salinity as indicated 
by the short-lived return of normal marine foraminifera in the Borków section (Peryt 2013a). Accordingly, during eustatic sea-level rise or tectonically triggered modification of the barrier between the open sea and the Carpathian Foredeep Basin, new marine water could enter this depression and bring with it a temporary pulse of marine fauna (Peryt 2001). However, this not necessarily led to the origin of microfauna-bearing strata, as described by Peryt (2013a) and in this paper, or to thin discontinuous lenticular limestone characterized by Peryt (2001), which is equivalent to unit ' $h$ ' in southern Poland (Kasprzyk 1993) and the marker bed 2 in western Ukraine (Peryt 2001). The unit clearly indicates considerable brine dilution and is mostly developed as clastic, laminated and redeposited gypsum forming an intercalation within a sabre gypsum unit. In western Ukraine the intercalation is passing shoreward into thin lenticular marine limestone indicating that this brine-dilution was not triggered by a climatically controlled influx of meteoric waters which have earlier caused the basinwide changes in salinity in most of the Carpathian Foredeep Basin, making possible the successful application of the event-stratigraphy methods (Bąbel 1999a, 1999b, 2005; Bąbel and Bogucki 2007; Peryt 2001, 2006). On the other hand, given the size of the Carpathian Foredeep Basin that is the largest European foredeep basin (see Oszczypko et al. 2006), no wonder that there are differences in the development of the gypsum facies between the western and eastern parts of the foredeep (Peryt et al. 1997; Peryt 2013b; Wysocka et al. 2016). In the westernmost part of the Badenian evaporite basin, in Moravia, clay intercalations and large pore structures between the selenite crystals occur (Peryt et al. 1997). The majority of the Moravian gypsum sequence is interpreted as originated in deeper, density-stratified waters, with a seawater layer present, as evidenced by the occurrence of an assemblage of Serravalian planktonic foraminifers in many parts of the gypsum sequence (Peryt et al. 1997: Fig. 7). The water circulation pattern in the Badenian evaporite basin of the Central Paratethys was quite complex: antiestuarine brine circulation is assumed for the Early and mid-Badenian (Báldi 2006), including the time interval of evaporite deposition (Bąbel and Becker 2006). In the Late Badenian, a reversal of circulation to estuarine type occurred (Báldi 2006). Relatively common microfossils found in clay intercalations within gypsum along the northern Carpathian Foredeep, in particular in Moravia, strongly suggest that there existed, as compared to the current reconstruction, an additional inflow channel. This channel was supplying the Polish Carpathian Basin from the south during the evaporite deposition and probably in the $300 \mathrm{kyr}$ following, during the generally low global sea-level (de Leeuw et al. 2018).

\section{Conclusions}

1) Short-lived temporary connections between the Central Paratethys and the Mediterranean existed during the middle Miocene Badenian Salinity Crisis.

2) This was facilitated by the palaeogeographical context, in particular by the location of the Badenian evaporite basin below the contemporaneous sea-level, and by the geotectonical context.

3) One of such connections left behind marine microfossils in a marly clay intercalation in the uppermost part of the gypsum sequence in SE Poland.

4) Both foraminiferal and dinoflagellate assemblages indicate brackish to normal marine salinity at inner shelf depths; however, dinoflagellate cyst assemblages that tolerate increased salinity are missing.

5) Marine palynomorphs (dinoflagellate cysts) and foraminiferal assemblages indicate a marine depositional environment of marly clay intercalation within gypsum sequence.

6) At the same time they strongly suggest that there existed additional, compared to the assumed so far, channels for marine organisms migration.

Abbreviations

AOM: Amorphous organic matter; TOC: Total organic carbon

\section{Acknowledgements}

We thank Krzysztof Leszczyński for his helpful suggestions on an early manuscript.

\section{Authors' contributions}

DP and TMP measured the section studied and collected the samples. DP identified and analyzed the foraminiferal assemblages and PG identified and analyzed the palynofacies and dinoflagellate cysts. The figures were prepared by DP (Figs. 3, 4 and 5 and a part of Fig. 6), PG (Figs. 7, 8 and 9 and a part of Fig. 6) and TMP (Figs. 1 and 2). The tables were done by DP (a part of Table 1) and PG (a part of Table 1, and Table 2). DP, PG and TMP drafted the manuscript. TMP did the final version of the manuscript that was then read and approved by DP and PG.

\section{Funding}

This study was jointly supported by the National Science Centre, Poland, grant No. UMO-2017/27/B/ST10/01129 to the first author and the statutory funds of the PGI-NRI (project 62.9012.1948.00.0 to the third author).

\section{Availability of data and materials}

The datasets and material analyzed in this study are available from the first two authors upon reasonable request.

\section{Competing interests}

The authors declare that they have no competing interests. All authors have approved this manuscript and no author has financial or other contractual agreements that might cause conflicts of interest. 


\section{Author details}

Institute of Paleobiology, Polish Academy of Sciences, Twarda 51/55, 00-818 Warszawa, Poland. ${ }^{2}$ Institute of Geological Sciences, Polish Academy of Sciences, Research Centre in Cracow, Senacka 1, 31-002 Kraków, Poland. ${ }^{3}$ Polish Geological Institute-National Research Institute, Rakowiecka 4, 00-975 Warszawa, Poland.

Received: 17 July 2019 Accepted: 8 April 2020

Published online: 05 June 2020

\section{References}

Alve, E., and J.W. Murray. 1999. Marginal marine environments of the Skagerrak and Kattegat: A baseline study of living (stained) benthic foraminiferal ecology. Palaeogeography Palaeoclimatology Palaeoecology 146: 171-193.

Bąbel, M. 1986. Growth of crystals and sedimentary structures in the sabre-like gypsum (Miocene, southern Poland). Przegląd Geologiczny 34: 204-208.

Bąbel, M. 1999a. Facies and depositional environments of the Nida gypsum deposits (middle Miocene, Carpathian Foredeep, southern Poland). Geological Quarterly 43: 405-428.

Bąbel, M. 1999b. History of sedimentation of the Nida gypsum deposits (middle Miocene, Carpathian Foredeep, southern Poland). Geological Quarterly 43: 429-447.

Bąbel, M. 2004. Badenian evaporite basin of the northern Carpathian Foredeep as a drawdown salina basin. Acta Geologica Polonica 54:313-337.

Bąbel, M. 2005. Selenite-gypsum microbialite facies and sedimentary evolution of the Badenian evaporite basin of the northern Carpathian Foredeep. Acta Geologica Polonica 55: 187-210.

Babel, M. 2007. Depositional environments of a salina-type evaporite basin recorded in the Badenian gypsum facies in the northern Carpathian Foredeep. Geological Society Special Publication 285: 107-142.

Bąbel, M., and A. Becker. 2006. Cyclonic brine-flow pattern recorded by oriented gypsum crystals in the Badenian evaporite basin of the northern Carpathian Foredeep. Journal of Sedimentary Research 76: 996-1011.

Bąbel, M., and A. Bogucki. 2007. The Badenian evaporite basin of the northern Carpathian Foredeep as a model of a meromictic selenite basin. Geological Society Special Publications 285: 219-246.

Báldi, K. 2006. Paleoceanography and climate of the Badenian (middle Miocene, 16.4-13.0 ma) in the Central Paratethys based on foraminifera and stable isotope $\left(\delta^{18} \mathrm{O}\right.$ and $\left.\delta^{13} \mathrm{C}\right)$ evidence. International Journal of Earth Sciences 95:19-142.

Bernard, J.M. 1986. Characteristic assemblages and morphologies of benthic foraminifera from anoxic, organic-rich deposits: Jurassic through Holocene. Journal of Foraminiferal Research 16: 207-215.

Bernard, J.M., and B.K. Sen Gupta. 1999. Foraminifera in oxygen-depleted environments. In Modern foraminifera, ed. B.K. Sen Gupta, 201-216. Dordrecht: Kluwer.

Bicchi, E., F. Ferrero, and M. Gonera. 2003. Palaeoclimatic interpretation based on middle Miocene planktonic foraminifera: The Silesia Basin (Paratethys) and Monferrato (Tethys) records. Palaeogeography Palaeoclimatology Palaeoecology 196: 265-303.

Bradford, M.R., and D.A. Wall. 1984. The distribution of recent organic-walled dinoflagellate cysts in the Persian Gulf, Gulf of Oman, and northeastern Arabian Sea. Palaeontographica Abteilung B 192: 16-84.

Bukowski, K. 2011. Badenian saline sedimentation between Rybnik and Dębica ased on geochemical, isotopic and radiometric research (in Polish with English summary). Dissertations Monographs 236:1-184.

Buzas-Stephens, P., E.A. Pessagno Jr., and C.J. Bowen. 2003. Foraminiferal response to habitat disruption: Arroyo Colorado, Texas. Journal for Foraminiferal Research 33: 294-308.

Cendón, D.I., T.M. Peryt, C. Ayora, J.J. Pueyo, and C. Taberner. 2004. The importance of recycling processes in the middle Miocene Badenian evaporite basin (Carpathian foredeep): Palaeoenvironmental implications. Palaeogeography Palaeoclimatology Palaeoecology 212: 141-158.

Cicha, I., F. Rögl, C. Rupp, and J. Ctyroká. 1998. Oligocene-Miocene foraminifera of the Central Paratethys. Frankfurt am Main: Kramer. de Leeuw, A., K. Bukowski, W. Krijgsman, and K.F. Kuiper. 2010. Age of the Badenian salinity crisis: Impact of Miocene climate variability on the circum-Mediterranean region. Geology 38: 715-718.

de Leeuw, A., M. Tulburec, K.F. Kuiper, M.C. Melinte-Dobrinescu, M. Stoica, and W. Krijgsman. 2018. New ${ }^{40} \mathrm{Ar} /{ }^{39} \mathrm{Ar}$, magnetostratigraphic and biostratigraphic constraints on the termination of the Badenian salinity crisis: Indications for tectonic improvement of basin interconnectivity in southern Europe. Global and Planetary Change 169: 1-15.

Debeney, J.-P., L. Della Patrona, and H. Goguenheim. 2009. Colonization of coastal environments by foraminifera: Insight from shrimp ponds in New Caledonia (New Zealand). Journal of Foraminiferal Research 39: 249-266.

Dubicka, Z. 2019. Chamber arrangement versus wall structure in the highrank phylogenetic classisfication of foraminifera. Acta Palaeontologica Polonica 64: 1-18.

Edwards, L.E., and V.A.S. Andrle. 1992. Distribution of selected dinoflagellate cysts in modern marine sediments. In Neogene and Quaternary dinoflagellate cysts and acritarchs, ed. M.J. Head and J.H. Wrenn, 259288. College Station: American Association of Stratigraphic Palynologists Foundation.

Fiorini, F. 2004. Benthic foraminiferal associations from Upper Quaternary deposits of southeastern Po plain, Italy. Micropaleontology 50: 45-58.

Gedl, P. 1999. Palaeoenvironmental and sedimentological interpretations of the palynofacial analysis of the Miocene deposits from the Jamnica S-119 borehole (Carpathian Foredeep, Poland). Geological Quarterly 43: 479-492.

Gedl, P. 2016. Dinoflagellate cysts and palynofacies from the upper Badenian (middle Miocene) of the Roztocze area at Józefów and Żelebsko (Carpathian Foredeep Basin, Poland): Palaeoenvironmental implications. Annales Societatis Geologorum Poloniae 86:273-289.

Gedl, P., and D. Peryt. 2011. Dinoflagellate cyst, palynofacies and foraminiferal records of environmental changes related to the late Badenian (middle Miocene) transgression at Kudryntsi (western Ukraine). Annales Societatis Geologorum Poloniae 81:331-349.

Gedl, P., D. Peryt, and T.M. Peryt. 2016. Foraminiferal and palynological organic matter records of the upper Badenian (middle Miocene) deposits at Anadoly (marginal part of the Ukrainian Carpathian Foredeep Basin). Geological Quarterly 60: 517-536.

Guy-Ohlson, D. 1996. Prasinophycean algae. In Palynology: Principles and applications, 1, ed. J. Jansonius and D.C. McGregor, 181-189. Dallas: American Association of Stratigraphic Palynologists Foundation.

Hayward, B.W. 2014. "Monospecific" and near-monospecific benthic foraminiferal faunas, New Zealand. Journal of Foraminiferal Research 44: 300-315.

Hayward, B.W., C.J. Hollis, and H.R. Grenfell. 1997. Recent Elphidiidae (Foraminiferida) of the Southwest Pacific and fossil Elphidiidae of New Zealand. Institute of Geological and Nuclear Sciences Monograph, 16 (New Zealand Geological Survey), Paleontological Bulletin 72:1-166.

Hilgen, F.J., L.J. Lourens, J.A. Van Dam, A.G. Beu, A.F. Boyes, R.A. Cooper, W. Krijgsman, J.G. Ogg, W.E. Piller, and D.S. Wilson. 2012. The Neogene period. In The geologic time scale 2012, ed. F.M. Gradstein, J.G. Ogg, M. Schmitz, and G. Ogg, 923-978. Oxford: Elsevier.

John, C.M., G.D. Karner, E. Browning, R.M. Leckie, Z. Mateo, B. Carson, and C. Lowery. 2011. Timing and magnitude of Miocene eustasy derived from the mixed siliciclastic-carbonate stratigraphic record of the northeastern Australian margin. Earth and Planetary Science Letters 304: 455-467.

Jorissen, F.J., D.M. Barmavidjaja, S. Puskaric, and G.J. van der Zwaan. 1992. Vertical distribution of benthic foraminifera in the northern Adriatic Sea: The relation with organic flux. Marine Micropaleontology 19: 131-146.

Kaiho, K. 1994. Benthic foraminiferal dissolved-oxygen index and dissolved oxygen levels in the modern ocean. Geology 22: 719-722.

Kaminski, M.A. 2012. Calibration of the benthic foraminiferal oxygen index in the Marmara Sea. Geological Quarterly 56: 757-764.

Kasprzyk, A. 1989. Lithology of the Miocene sulfate deposits in the Staszów region. Geological Quarterly 33: 241-268 (in Polish with English summary).

Kasprzyk, A. 1993. Lithofacies and sedimentation of the Badenian (middle Miocene) gypsum in the northern part of the Carpathian Foredeep, southern Poland. Annales Societatis Geologorum Poloniae 63:33-84. 
Kasprzyk, A. 1995. Correlation of sulphate deposits of the Carpathian Foredeep at the boundary of Poland and Ukraine. Geological Quarterly 39: 95-108.

Kasprzyk, A. 1999. Sedimentary evolution of Badenian (middle Miocene) gypsum deposits in the northern Carpathian Foredeep. Geological Quarterly 43: 449-465.

Kasprzyk, A. 2005. Diagenetic alteration of Badenian sulphate deposits in the Carpathian Foredeep Basin, southern Poland: Processes and their succession. Geological Quarterly 49: 305-316.

Kendall, A.C. 2010. Marine evaporites. In Facies models, ed. N.P. James and R.W. Dalrymple, 4th ed., 505-540. St. John's: Geological Association of Canada.

Kouvenhoven, T.J., and G.J. van der Zwaan. 2006. A reconstruction of late Miocene Mediterranean circulation patterns using benthic foraminifera. Palaeogeography Palaeoclimatology Palaeoecology 238: 373-385.

Kováč, M., N. Hudáčková, E. Halásová, M. Kováčová, K. Holcová, M. Oszczypko-Clowes, K. Báldi, G. Less, A. Nagymarosy, A. Ruman, T. Klučiar, and M. Jamrich. 2017. The Central Paratethys palaeoceanography: A water circulation model based on microfossil proxies, climate, and changes of depositional environment. Acta Geologica Slovaca 9:75-114.

Kubica, B. 1992. Lithofacial development of the Badenian chemical sediments in the northern part of the Carpathian Foredeep. Prace Państwowego Instytutu Geologicznego 133: 1-64 (in Polish with English summary).

Kubica, B. 1994. Lithogeophysical correlation of the Badenian chemical deposits of the Carpathian Foredeep (southern Poland). Przeglad Geologiczny 42: 759-765 (in Polish with English summary).

Kwiatkowski, S. 1972. Sedimentation of gypsum in the Miocene of southern Poland. Prace Muzeum Ziemi 19: 3-93 (in Polish with English summary).

Langer, M. 1993. Epiphytic foraminifera. Marine Micropaleontology 20: 235-265.

Loeblich, A.R., Jr., and H. Tappan. 1987. Foraminiferal genera and their classification. New York: Van Nostrand Reinhold.

Loubere, P. 1997. Benthic foraminiferal assemblage formation, organic carbon flux and oxygen concentrations on the outer continental shelf and slope. Journal of Foraminiferal Research 27: 93-100.

Moodley, L., and C. Hess. 1992. Tolerance of infaunal benthic foraminifera for low and high oxygen conditions. Biological Bulletin 183: 94-98.

Murray, J.W. 1968. Living foraminifers of lagoons and estuaries. Micropaleontology 14: 83-96.

Murray, J.W. 1991. Ecology and Palaeoecology of benthic foraminifera. Avon: Longman.

Murray, J.W. 2006. Ecology and applications of benthic foraminifera. Cambridge: Cambridge University Press.

Odrzywolska-Bieńkowa, E. 1975. Micropaleontological stratigraphy of the Miocene of central part of the Carpathian Foredeep (in Polish with English summary). Przeglad Geologiczny 23:597-603.

Orti Cabo, F., J.J. Pueyo Mur, D. Geisler-Cussey, and N. Dulau. 1984. Evaporitic sedimentation in the coastal salinas of Santa Pola (Alicante, Spain). Revista di Investigacións Geologiques 38 (39):169-220.

Osmólski, T. 1976. Karst and the origin of sulphur deposits in Poland. Geological Quarterly 20:559-571 (in Polish with English summary).

Oszczypko, N., P. Krzywiec, I. Popadyuk, and T. Peryt. 2006. Carpathian Foredeep Basin (Poland and Ukraine): Its sedimentary, structural, and geodynamic evolution. American Association of Petroleum Geologists Memoir 84: 293-350

Palcu, D.V., L.A. Golovina, Y.V. Vernyhorova, S.V. Popov, and W. Krijgsman. 2017. Middle Miocene paleoenvironmental crises in Central Eurasia caused by changes in marine gateway configuration. Global and Planetary Change 158: 57-71.

Palcu, D.V., M. Tulbure, M. Bartol, T.J. Kouwenhoven, and W. Krijgsman. 2015. The Badenian-Sarmatian extinction event in the Carpathian foredeep basin of Romania. Paleogeographic changes in the Paratethys domain. Global and Planetary Change 133: 346-358.

Pawlowski, J., M. Holzmann, and J. Tyszka. 2013. New supraordinal classification of foraminifera molecules meet morphology. Marine Micropaleontology 100: 1-10.

Pawłowski, S., K. Pawłowska, and B. Kubica. 1985. Geology of the Tarnobrzeg native Sulphur deposit. Prace Instytutu Geologicznego 114: 1-109 (in Polish with English summary).
Peryt, D. 2013a. Foraminiferal record of marine transgression during deposition of the middle Miocene Badenian evaporites in central Paratethys (Borków section, polish Carpathian Foredeep). Terra Nova 25: 298-306.

Peryt, D., and P. Gedl. 2010. Palaeoenvironmental changes preceding the middle Miocene Badenian salinity crisis in the northern polish Carpathian Foredeep Basin (Borków quarry) inferred from foraminifers and dinoflagellate cysts. Geological Quarterly 54: 487-508.

Peryt, D., P. Gedl, and T.M. Peryt. 2014. Foraminiferal and palynological records of the late Badenian (middle Miocene) transgression in Podolia (Shchyrets near Lviv, western Ukraine). Geological Quarterly 58: 465-484.

Peryt, D., and T.M. Peryt. 2009. Environmental changes in the declining middle Miocene Badenian evaporite basin of the Ukrainian Carpathian Foredeep (Kudryntsi section). Geologica Carpathica 60: 505-517.

Peryt, T.M. 1996. Sedimentology of Badenian (middle Miocene) gypsum in eastern Galicia, Podolia and Bukovina (West Ukraine). Sedimentology 43: 571-588.

Peryt, T.M. 2000. Resedimentation of basin centre sulphate deposits: Middle Miocene Badenian of Carpathian Foredeep, southern Poland. Sedimentary Geology 134:331-342.

Peryt, T.M. 2001. Gypsum facies transitions in basin-marginal evaporites: Middle Miocene (Badenian) of West Ukraine. Sedimentology 48: 1103-1119.

Peryt, T.M. 2006. The beginning, development and termination of the middle Miocene Badenian salinity crisis in Central Paratethys. Sedimentary Geology 188-189:379-396.

Peryt, T.M. 2013b. Palaeogeographical zonation of gypsum facies: Middle Miocene Badenian of Central Paratethys (Carpathian Foredeep in Europe). Journal of Palaeogeography 2:225-237.

Peryt, T.M., and M. Jasionowski. 1994. In situ formed and redeposited gypsum breccias in the middle Miocene Badenian of southern Poland. Sedimentary Geology 94: 153-163.

Peryt, T.M., S. Karoli, D. Peryt, O.I. Petrichenko, P. Gedl, W. Narkiewicz, J. Durkovičova, and Z. Dobieszyńska. 1997. Westernmost occurrence of the middle Miocene Badenian gypsum in Central Paratethys (Kobeřice, Moravia, Czech Republic). Slovak Geological Magazine 3:105-120.

Peryt, T.M., and A. Kasprzyk. 1992. Carbonate-evaporite sedimentary transitions in the Badenian (middle Miocene) basin of southern Poland. Sedimentary Geology 76: 257-271.

Peryt, T.M., D. Peryt, M. Jasionowski, A.V. Poberezhskyy, and T. Durakiewicz. 2004. Post-evaporitic restricted deposition in the middle Miocene ChokrakianKaraganian of East Crimea (Ukraine). Sedimentary Geology 170: 21-36.

Richter, G. 1964. Zur Ökologie der Foraminifera I: Die Foraminiferen Gesellschaften der Jadesgebietes. Natur und Museum 94:343-353.

Rögl, F. 1998. Palaeogeographic considerations for Mediterranean and Paratethys seaways (Oligocene to Miocene). Annalen des Naturhistorischen Museums Wien 99A: 279-310.

Schiebel, R., and C. Hemleben. 2017. Planktic foraminifers in the modern ocean. Berlin:Springer.

Sen Gupta, B.K., and M.-L. Machain-Castillo. 1993. Benthic foraminifera in oxygen-poor habitats. Marine Micropaleontology 20: 183-202.

Simon, D., D. Palcu, P. Meijer, and W. Krijgsman. 2019. The sensitivity of middle Miocene paleoenvironments to changing marine gateways in Central Europe. Geology 47: 35-38.

Śliwiński, M., M. Bąbel, K. Nejbert, D. Olszewska-Nejbert, A. Gąsiewicz, B.C. Schreiber, J.A. Be-Nowitz, J. A, and P. Layer. 2012. Badenian-Sarmatian chronostratigraphy in the Polish Carpathian Foredeep. Palaeogeography Palaeoclimatology Palaeoecology 326-328:12-29.

Szczechura, J. 2000. Age and evolution of depositional environments of the supra-evaporitic deposits in the northern, marginal part of the Carpathian Foredeep: micropalaeontological evidence. Geological Quarterly 44: 81-100.

Vaniček, V., M. Juračić, Z. Bajraktarević, and V. Ćosović. 2000. Benthic foraminiferal assemblages in a restricted environment - An example from the Mljet Lakes (Adriatic Sea, Croatia). Geologia Croatica 53: 269-279.

Verhallen, P. 1991. Late Pliocene to early Pleistocene Mediterranean muddwelling foraminifera: Influence of a changing environment on community structure and evolution. Utrecht Micropaleontological Bulletin 40: 1-219.

Walton, W.R., and B.J. Sloan. 1990. The genus Ammonian Brünnich, 1772: Its geographic distribution and morphologic variability. Journal of Foraminiferal Research 20: 128-156. 
Warren, J.K. 2016. Evaporites: A geological compendium, 1813. Berlin: Springer. Wysocka, A., A. Radwański, M. Górka, M. Bąbel, U. Radwańska, and M. Złotnik. 2016. The middle Miocene of the fore-Carpathian Basin (Poland, Ukraine and Moldova). Acta Geologica Polonica 66: 351-401.

Zaninetti, L. 1982. Les foraminiferes des marais salant de Salin-de-Giraud (Sud de la France): Milieu de vie et transports dans le Salin, comparaison avec les microfaunes marines. Géologie méditerranéenne 9: 447-470.

\section{Publisher's Note}

Springer Nature remains neutral with regard to jurisdictional claims in published maps and institutional affiliations.

\section{Submit your manuscript to a SpringerOpen ${ }^{\circ}$ journal and benefit from:}

- Convenient online submission

- Rigorous peer review

- Open access: articles freely available online

- High visibility within the field

- Retaining the copyright to your article

Submit your next manuscript at $\boldsymbol{\nabla}$ springeropen.com 